Chapman University

Chapman University Digital Commons

Philosophy Faculty Articles and Research

Philosophy

1981

\title{
Professional and Ordinary Morality: A Reply to Freedman
}

Mike W. Martin

Chapman University,mwmartin@chapman.edu

Follow this and additional works at: http://digitalcommons.chapman.edu/philosophy_articles

Part of the Ethics and Political Philosophy Commons

\section{Recommended Citation}

Martin, Mike W. "Professional and Ordinary Morality: A Reply to Freedman." Ethics (1981): 631-633.

DOI: $10.1086 / 292276$

This Response or Comment is brought to you for free and open access by the Philosophy at Chapman University Digital Commons. It has been accepted for inclusion in Philosophy Faculty Articles and Research by an authorized administrator of Chapman University Digital Commons. For more

information, please contact laughtin@chapman.edu. 


\section{Professional and Ordinary Morality: A Reply to Freedman}

Comments

This article was originally published in Ethics in 1981. DOI: 10.1086/292276

\section{Copyright}

University of Chicago Press 


\section{Professional and Ordinary Morality: A Reply to Freedman}

\section{Mike W. Martin}

After rereading Freedman's original essay, I still find my earlier interpretations to be legitimate renderings of the essay. I must apologize, however, for not supplying the further exegesis warranted by his astute "Response." I want to use the allotted space for clarifying further the substantive issues over which we differ concerning the relationship between professional and ordinary morality.

The following is a list of a few things that might be meant in drawing a distinction between professional and ordinary morality. They constitute only rough sketches of definitions based upon, respectively, de facto standards, the content of justified principles, the origin of justified principles, and professional status viewed as an act-permitting condition: (1) Professional morality consists of the standards endorsed by professionals or professional societies. Ordinary morality is the set of standards people endorse in their nonprofessional, private lives. (2) Professional morality is the set of binding moral obligations to which professionals ought to be committed because of their special skills, functions, working milieu, etc. Ordinary morality is the set of valid moral considerations and morally correct judgments considered in abstraction from the special context of the professions and the specific moral obligations of professionals. (3) Ordinary morality in some sense 'emanates from' or has its origin (or justification?) in basic features of the human condition, whereas professional morality derives from the special roles of professionals. (4) Professional morality is a set of valid moral principles which sometimes requires acts that are immoral for anyone except persons having professional status. Ordinary morality is the set of considerations which would make the acts immoral in the case of nonprofessional agents.

We may set aside 1 . In my earlier essay I ascribed 2 to Freedman, not 3. In his "Response," Freedman commits himself to the combination of 3 and 4. Following Freedman's lead, I want to focus on 4. In his words, it "requires that professional morality call upon us to do acts (or to refrain from doing acts) whose omission (or performance) would be immoral, save for the fact of the actor's professional identity." Ordinary morality consists in what a person "would be obliged to do save for the fact of belonging to this profession." These are presented in the "Response" as 
stipulative definitions, and not as substantive, argued-for, normative conclusions. They make ordinary and professional morality logically incompatible as a matter of definitional necessity. Using these definitions, it is plain that there are professional moralities, and there is, in particular, a medical-profession morality. For example, because I am not a doctor it is immoral for me to perform open-heart surgery, but it is permissible for cardiovascular surgeons to perform them, and this is because of their particular professional status. Again, as Freedman argued, there are some acts of maintaining confidentiality which are immoral for nondoctors but permissible for doctors.

It is crucial to emphasize that these definitions leave open the question as to precisely why having a professional identity makes certain acts moral which would otherwise be immoral. For being a professional involves a complex of special properties, any one or several of which might be the morally decisive factor in a given case. Some of these properties may be grouped into the following categories: (a) ability set: possessing particular skills and expert knowledge; $(b)$ function set: applying those skills and that knowledge in the course of performing designated functions within appropriate situations; $(c)$ responsibility set: being charged with promoting a particular social good, and having special moral responsibilities and obligations based upon both this good and the ways professional activities impact on moral rights; and (d) authorization set: being an official member of a profession, where a profession is a social institution granted unique privileges and legal rights by a society which desires professional zealousness.

Freedman emphasizes $d$ as the key factor which justifies a professional's individual actions. Granting the possible relevance of $d$, I would emphasize instead $a$ through $c$. (It was primarily $a$ and $b$ which I had in mind in my earlier essay when I spoke of the "circumstances of medical practice.") Moreover, I would emphasize $a$ through $c$ in justifying both individual acts and institutional norms, thus invoking them at both of Freedman's "two tiers." What is important to keep clear is that this is a substantive normative issue left open by Freedman's definitions. He would be begging the question if he simply built into his definitions of "professional morality" that $d$ is decisive.

With this background, I want to make three comments. First, Freedman's position is still open to the fundamental objection that an appeal to privilege-privilege based on social consent and society's desire for professional zealousness-is insufficient to justify morally (as opposed to legally) pledging oneself to professional norms and is also insufficient to justify those norms themselves. For the question of the moral reasonableness of society's consent and desires, all things considered, has to be addressed. Here $a$ through $c-\operatorname{not} d$-are crucial, as well as are considerations from everyday morality. To use an extreme example, the mere fact that a society gave a Hitlerian authorization to doctors to fanatically pursue their dedication to health by conducting inhumane experiments 
on Jews (in order to obtain new medical knowledge) would not suffice to justify the acts of those doctors. The unreasonableness of this society's desires and its institutional privilege thwarts the appeal to membership in the institution as a justification of individual acts. Similarly, authorized membership in the medical profession cannot by itself justify invoking the confidentiality privilege, for it needs to be justified in terms of $a$ through $c$. And I believe it can be shown to be justified to a greater extent than can confidentiality in the more purely money-based relationships involved in Freedman's examples of the accountant and the city engineer.

Second, Freedman's attack on deontological justifications for pledging oneself to professional norms (which I viewed as an attack on deontological justifications of professional norms) turns on equating "contravening ordinary morality" with "doing evil." Freedman maintains this view in his "Response": "At the point of entry into a privileged profession the aspirant is engaged in a promise to do evil." But using the definition of "professional morality" given in his "Response," there is no basis for this claim. The aspirant is not promising to do evil, flat out, but only promising to do acts which would be immoral, save for the fact he will have professional identity at the time he performs them. Freedman says precisely this in his later elaboration of the (apparently contradicting) remark that the aspirant's pledge "is saved from being a promise to do evil." Since it is not really a promise to do evil, his earlier attack on deontological perspectives is vitiated. Trying to avoid this objection by inventing special senses of "evil," defined in terms of different moralities, is needlessly obfuscating. And the same can be said of his statement that what the aspirant is doing "is exchanging a moral point of view for another legitimate moral world." This heady talk, reminiscent of Nietzsche's leap beyond good and evil, is a misleading way of saying that the special features of the professional world are morally relevant in assessing a person's obligations.

Finally, the importance of pursuing the appeal to rights, understood in deontological rather than utilitarian terms, seems to me all the more pressing given Freedman's concluding remarks in the "Response." $\mathrm{He}$ avers that the patient's right to privacy, and hence to confidentiality, is "created through a grant to the profession of privilege." There are grounds for concern here! The individual patient is placed in double jeopardy when his or her rights are treated as contingent upon a privilege granted by one social unit (a country) to another social unit (a profession). The moral right to privacy is not the offspring of a legal or institutional right; rather, the legal or institutional right should be established in order to insure protection of the moral right. 